\title{
EVALUATION OF TWO METHODS OF TRACINGS FOR IMPLANTS IN PANORAMIC RADIOGRAPHS
}

\author{
AVALIAÇÃO DE DOIS MÉTODOS DE TRAÇADOS PARA IMPLANTES EM \\ RADIOGRAFIAS PANORÂMICAS
}

\author{
Deborah Queiroz de FREITAS \\ MSci in Dental Radiology by Faculdade de Odontologia de Piracicaba, Universidade de Campinas - UNICAMP.
}

Agenor MONTEBELLO FILHO. DDS, PhD

Associate Professor, Department of Oral Diagnosis, Oral Radiology, Faculdade de Odontologia de Piracicaba, Universidade de Campinas UNICAMP.

\begin{abstract}
Tn the last years, computer programs have appeared in order to help dental practitioners in implants planning.
1 These programs aim to facilitate the acquisition of adequate measures in digitalized radiographs. The aims of this study were: to evaluate the intra-examiner agreement in the acquisition of measures using two methods (manual and computer program - Radioimp), comparing their performances. Three examiners analyzed twenty-one panoramic radiographs. They used the two methods in two occasions. In the manual method, the examiners made a tracing on a paper fixed to the images and measured nine regions with a caliper. The images were digitalized and showed in a computer screen to be analyzed in the computer program. The examiners acquired measures of the same regions by the manual method. Vertical measures of spheres in the images were acquired in order to discount the magnifying factor of the technique. Through statistics analysis ( $\mathrm{p}=.05$ ), it was possible to conclude that there were differences in intra-examiner agreement and the examiners had greater difficulty in reproducing the measures when they used the computer program; the measures acquired by the manual method were closer to the real ones.
\end{abstract}

UNITERMS: Panoramic radiography; Software; Dental implantation endosseous.

\section{INTRODUCTION}

The success of treatments with implants depends on many factors, such as pre-surgical evaluation of the patient. In this phase, radiographs aim at the evaluation of anatomical aspects of the region, as well as the quality and the amount of the remaining bone. They should also allow acquisition of similar to the real measures ${ }^{2,5,11}$.

Intraoral radiographs (conventional periapical, digital periapical and occlusal techniques) and extraoral imaging (panoramic radiographs, lateral cephalometric radiographs, linear tomography and computed tomography) have been used in implant treatment planning ${ }^{5,11}$.

Panoramic radiography is a very popular and widely accepted technique of the oral region ${ }^{1}$. In cases of implant planning, it has been used as first examination to provide wide anatomic visualization.

To obtain measures of the remaining bone, tracings on the image have to be performed. This is frequently done manually ${ }^{1,11,12,13}$.

This manual method is difficult; therefore, in the last years, computer programs for implant planning have facilitated the acquisition of adequate measures by using digital imaging which leads to better results ${ }^{6,7}$.

These programs also allow the images to be amplified, modified regarding contrast, brightness, tonality and inversion of the tone scale can be done. They make the communication between patients, dental surgeons and radiologists easier. The images can be sent quickly by means of Internet. The professionals can use programs like Radioimp (Radiomemory, Belo Horizonte, Brazil), Planimp (CDT, Cuiabá, Brazil) and SIM/Plant (Columbia Scientific Incorporation, Columbia, the USA).

However, there are no studies about the accuracy of measures obtained with these programs ${ }^{7}$. Since their use has increased, the evaluation of these measures becomes important.

The aim of this study is to evaluate the intra-examiner agreement in the acquisition of measures using two methods (manual and a computer program) and to evaluate their performance. 


\section{MATERIALAND METHODS}

Twenty-one panoramic radiographs of edentulous human dry skulls were used. For acquisition of the images, steel spheres were fixed on alveolar crest of the incisor, cuspid, bicuspid and molar superior and inferior. The images were analyzed by three radiologists using the manual method (method 1 ) and after 10 days by means of a computer program (method 2). This sequence of evaluation was repeated resulting in two analyses for each method. Each examiner received instructions about the methods. They were not trained because the objective of this study was to evaluate a computer program when it was used by professionals without a previous training ${ }^{2,12}$.

In the manual method, the examiners used a light box and a mask to trace the images of the anatomical structures on a paper fixed to the radiographs. They made tracings for implants and measured them in nine regions: (Figure 1)

- superior incisors (region 1);

- $\quad$ superior cuspids (region 2);

- superior bicuspids (region 3);

- superior molars (region 4);

- inferior molars (region 5);

- inferior bicuspids (region 6);

- inferior cuspids (region 7);

- inferior incisors (region 8);

- $\quad$ inferior molar until the mandibular canal (region 9).

The measures were obtained using a caliper.

The images were digitalized in a Scan Jet 4c/T (Hewlett Packard) scanner with a transparency reader, 256 dpi (dots per inch) resolution, according to instruction of the manufacturer's implant planning program (Radioimp version 2000 - Radio Memory Ltda, Belo Horizonte, MG, Brazil). For the analysis, the examiners could use the tools of the program, such as modification of brightness, contrast, magnification of the image (zoom) and inversion of tone scale. The examiners did a tracing on digital images like that performed by the manual method, using the mouse. The measures appeared automatically in the inferior region of the screen.

Vertical measures of the spheres of each region of each radiography were determined by the same procedure of the manual method in order to deduct the image magnification to make possible the comparison of these with the real ones.

Due to the inclination and asymmetry of the jaws, the direct acquisition of the real measures on them could produce incorrect results. Thus they were sectioned in the place where each steel sphere was fixed initially to obtain the real measures. The slices had been fixed with adhesive ribbon on the sensitive surface of a chassis and radiographs were performed in the cephalometric norm. The close contact between the slices and the film and the distance of $1.52 \mathrm{~m}$ between the source of X-rays and the film provided clear images with reliable dimensions. It was possible to obtain the highest bony height of each region using a caliper in these radiographs since they are bidimensional $^{8}$.

\section{Statistical analysis}

Paired tests were applied: Student's t test, Wilcoxon signed rank test or sign test. Selection was made by an assumption study. Student's t test requires studied differences to be based on normally distributed data. A first tool in the study of assumptions was the ShapiroWilk test, which tested the hypothesis that the data were from a normally distributed population. If this was not the

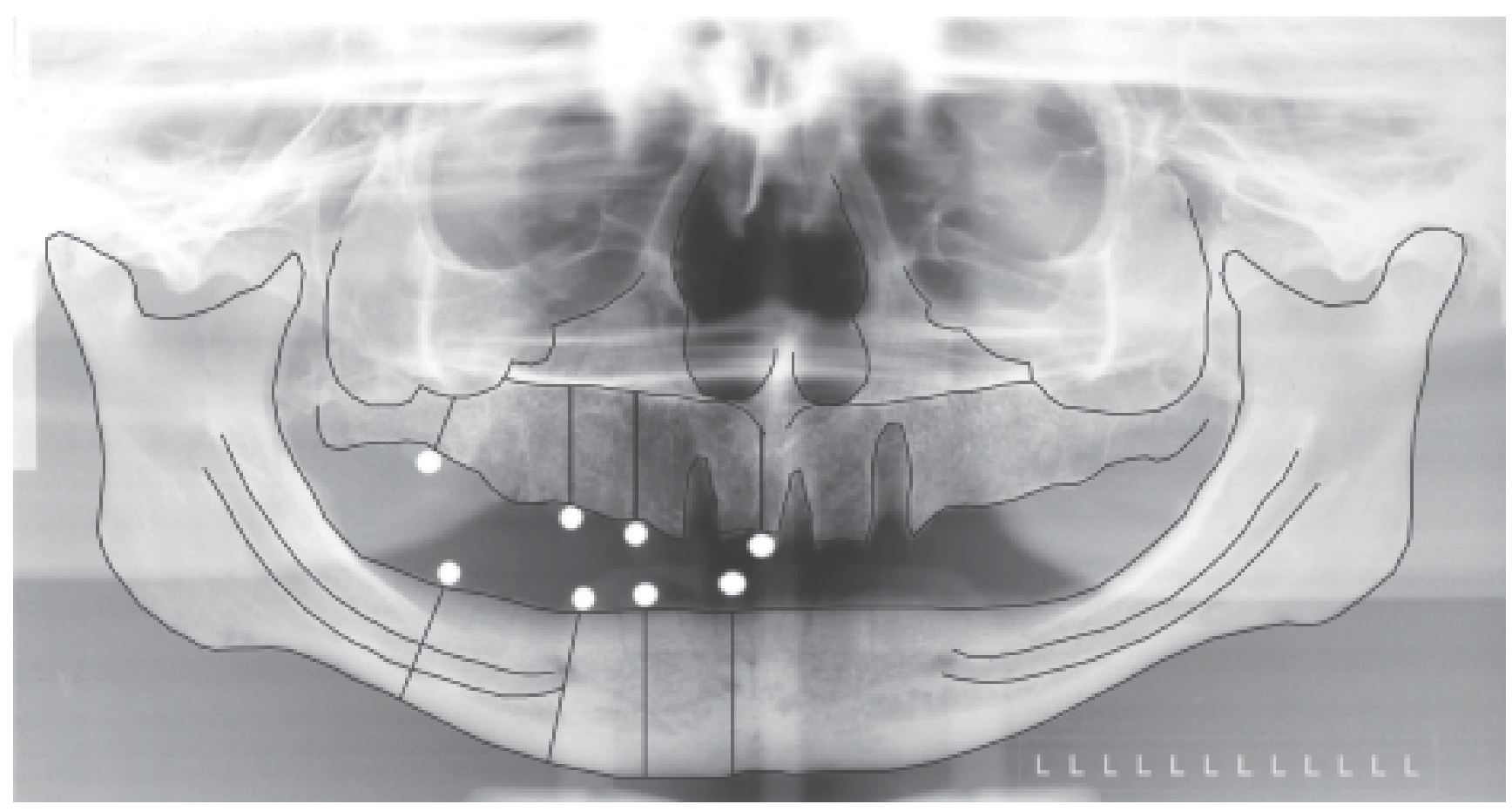

FIGURE 1- Manual tracing in panoramic radiography 
case, we applied the Wilcoxon signed rank test or sign test. The selection between them was made on the basis of skewness. Values of this coefficient between -2 and +2 indicate skewness of the data and Wilcoxon signed rank test could be used. If the population was not normal and there was no skewness, we applied the sign test. The significance level was $5 \%(\mathrm{p}=.05)$. The analysis was made using the SAS, version 8.02, 1998 program (Statistical Analysis Sistems Institute Inc., USA).

\section{RESULTS}

\section{Intra-examiner agreement}

This evaluation concers the differences between the radiographic measures in the two times of analysis.

According to the statistical analysis, there were significant differences between the averages for examiner 1 in only two measures: region 3 - method $1(p=.01)$ and region 9 - method $2(\mathrm{p}=.04)$. There were significant differences for examiner 2 in four measures: region 5 methods 1 and 2 ( $\mathrm{p}=.01$ and $\mathrm{p}=.001$, respectively), region 6 - method $2(\mathrm{p}=.01)$ and region 7 - method $2(\mathrm{p}=.01)$. And there were significant differences in six situations for examiner 3: region 1 - method $2(p=.01)$, region 4 - method 2 $(\mathrm{p}=.001)$, region $5-$ method $2(\mathrm{p}=.01)$, region $6-$ method 2 $(\mathrm{p}=.01)$, region $8-2$ method $(\mathrm{p}=.04)$ and region 9 - method $2(\mathrm{p}=.03)$.

\section{Comparison between the methods}

The radiographic measures obtained by the examiners were compared with the real ones for comparison between the methods. There were significant differences in $46.3 \%$ of the measures. $68 \%$ of these were obtained when the examiners used the computer program (method 2) and only $32 \%$ of them were obtained when they used the manual method (method 1). It was also possible to verify that in situations where there was a significant difference of measures by the computer program, most $(92.86 \%)$ were greater than the real. In situations where there was a significant difference of measures by the manual method, they were greater than the real ones in $60 \%$ of the cases.

\section{DISCUSSION}

The need for accurate measures in implant planning has produced changes in the field of dental radiology ${ }^{5}$. This field plays an important role in all phases of this kind of treatment. These alterations aim at the acquisition of images that allow to obtain measures closer to the real ones and include the use of guides in the execution of the radiographs and the development of tomographs. Recently computer programs have appeared to aid the professionals in implant planning, .

Here two methods of tracings on panoramic radiographs were studied to obtain measures in edentulous areas. Panoramic radiography was used because it is widely utilized in Dentistry and Implantodontics.

Due to difficulty in the tracings as well as in obtention of the measures, the examiners performed them on two occasions for evaluation of intra-examiner agreement. Regarding the results, an expressive variation was observed between the abilities of the examiners, since examiner 1 did not reproduce the measures in only two of the 18 situations and examiner 3 did not reproduce them in six situations. Thus we agree with Todd, et al. ${ }^{12}$ (1993) who, although using conventional tomography in their study, also found significant differences between the tracings and the measures obtained by four members of a dental implant team in implant planning. The results of the study by Bou Serhal, et al. ${ }^{2}$ (2002) equally indicated intraexaminer variation in the obtention of measures. The results also agree with Sewell, et al. ${ }^{10}$ (1997) who affirmed that the diagnosis depends on the ability of the observer and with Schulze, et al. ${ }^{9}$ (2000) who indicated variation of the examiner as one of the sources of error in the obtention of measures.

However the results differ from the results by Xie, et al. ${ }^{13}$ (1996) since these authors found good intra-examiner agreement in the obtention of measures. The difference between the studies is that the former was performed by only one examiner. The analysis of one examiner can mask the results, once examiner 1 presented good performance. If only this one made the evaluation, the results would not be real, since they would be masking the lack of agreement of the other examiners and consequently the personal variation in radiographic interpretations.

In the present study two of the three examiners presented a greater difficulty in the reproductions of the measures when they used the computer program.

The factor of magnification of each region was deducted before the comparison with the real measures for evaluation of the accuracy ${ }^{5,8,11}$. The objective was to eliminate the influence of the magnification of the panoramic radiography on the results. These magnification factors were calculated from the measures of the images of the spheres and their real measures according to Tal, Moses ${ }^{11}$ (1991).

Based on the study of the accuracy of the measures, an evaluation of the use of a computer program for implant planning could be performed. This evaluation is important because there is a scarcity of studies in the literature about these programs ${ }^{6}$, specially Radioimp. The majority of the radiographic measures that differed from the real ones was obtained by the computer program. Moreover, most of these measures were greater than the real ones, a fact that could be more prejudicial than smaller measures in implant plannings. The results differ from those by Camacho, et al. ${ }^{3}$ (1999). These authors found that the analysis by the digital method was more accurate when compared with the manual tracing. They differ from the results by Fonteles ${ }^{4}$ (2002), because there were no significant differences between the manual and computer program methods. 
However in the last study the tracings were done on the images before their digitalization. This fact may have led to less variation between the measures, because the examiners did not do the tracing. They only obtained the measures. Besides they used other computer program (Planimp - CDT, Cuiabá, Brasil).

Regarding the digital analysis of images, Schulze, et al. ${ }^{9}$ (2000) found that measures obtained without magnification of the image were more accurate when compared with measures obtained in a magnified image. They recommended the images to be analyzed without the use of available magnification in the program.

In addition to the mentioned interference of the magnification of the image, the examiners may have had difficulty in the management of the "mouse". Thus it is not prudent to consider the program responsible for the differences between the radiographic measures and the real ones. However it is recommendable that the programs for implant plannings be used cautiously because in these cases an overestimation can result in disagreeable situations for the professional and the patient ${ }^{2}, 12$.

After analysis of the results we concluded that the examiners presented a difference in the ability for the reproduction of the measures and they had greater difficulty in the reproduction of the measures when they used the computer program. The majority of the measures that presented a difference when compared to the real ones was obtained by the computer program. The measures acquired by the manual method were closer to the real ones, therefore the computer programs must be used with caution by trained professionals.

\section{RESUMO}

Nos últimos anos, surgiram, na Odontologia, programas de computador para auxiliar o profissional no planejamento de implantes. Esses programas visam facilitar a obtenção de medidas adequadas em exames radiográficos digitalizados. Os objetivos desse trabalho foram: avaliar a concordância intra-examinador na obtenção de medidas por dois métodos (o manual e o com um programa de computador - Radioimp); e comparar o desempenho dos dois métodos. Para isso, 21 radiografias panorâmicas foram analisadas por três avaliadores, pelos dois métodos, em duas ocasiões. No método manual, os avaliadores realizaram um traçado sobre papel acetato fixado às imagens, e, com um paquímetro, obtiveram medidas de nove regiões. Para a análise das imagens no programa de computador, essas foram digitalizadas e exibidas em uma tela de computador. Os avaliadores obtiveram medidas das mesmas regiões analisadas pelo método manual. Para desconto da ampliação inerente à técnica, foram obtidas medidas verticais de esferas presentes nas imagens. Os resultados foram submetidos à análise estatística $(\mathrm{p}=0.05)$. Houve diferenças entre os avaliadores na concordância intra-examinador, sendo que esses apresentaram maior dificuldade na reprodução das medidas, quando utilizaram o programa de computador; a maioria das medidas que apresentaram falta de exatidão foi obtida ao se utilizar o mesmo programa. Dessa forma, os programas destinados ao planejamento de implantes devem ser utilizados com cautela por pessoas treinadas.

UNITERMOS: Radiografia panorâmica; Programas de computador, Implante dentário endoósseo.

\section{ACKNOWLEDGMENT}

The present study was supported by CAPES.

\section{REFERENCES}

1- Amir C, Asja C, Melita VP, Adnan C, Vjekoslav J, Muretic I. Evaluation of the precision of dimensional measurements of the mandible on panoramic radiographs. Oral Surg Oral Med Oral Pathol Oral Radiol Endod1998 Aug; 86(2):242-8.

2- Bou Serhal C, Jacobs R, Flygare L, Quirynen M, Steenberghe D. Perioperative validation of localisation of the mental foramen. Dentomaxillofac Radiol 2002 Jan; 31(1):9-43.

3- Camacho HM, Falla AO, Parra SMO, Delgado AC, Delgado GC. Análisis radiográfico convencional y digital computadorizado en evaluación ósea para la colocación de implantes. Universitas Odontol 1999 Nov; 19(39):9-13.

4- Fonteles SMS. Estudo comparativo de mensuração radiográfica em cortes tomográficos convencionais por métodos informatizados. Piracicaba, 2002. Tese (Doutorado - Radiologia Odontológica) - Faculdade de Odontologia de Piracicaba, Universidade Estadual de Campinas.

5- Frederiksen NL. Diagnostic imaging in dental implantology. Oral Surg Oral Med Oral Pathol Oral Radiol Endod 1995 Nov; 80(5):540-54.

6- Hagiwara Y, Koizume M, Igarashi T. Application of CT imaging for implant simulation. J Oral Sci 1999 Dec; 41(4):157-61.

7- Kraut RA. Interactive CT diagnostics, planning and preparation for dental implants. Implant Dent 1998; 7(1):19-25.

8- Montebello Filho A. Avaliação da fidelidade das imagens obtidas de crânios secos, por meio de exames radiográficos convencionais (intra e extra-bucais) e tomográficos (panorâmico, convencional e computadorizado) em comparação com anatomia óssea topográfica. Piracicaba, 2000. Tese (Livre Docência Radiologia Odontológica) - Faculdade de Odontologia de Piracicaba, Universidade Estadual de Campinas.

9- Schulze R, Krummenauer F, Schalldach F, Hoedt B. Precision and accuracy of measurements in digital panoramic radiography. Dentomaxillofac Radiol 2000 Jan; 29(1):52-6.

10- Sewell CM, Pereira MF, Varoli OJ. Princípios de produção da imagem digitalizada. RPG 1997 jan/mar; 4(1):55-8. 
11- Tal H, Moses O. A comparison of panoramic radiography with computed tomography in the planning of implant surgery.

Dentomaxillofac Radiol 1991 Feb; 20(1):40-2.

12- Todd AD, Gher ME, Quintero G, Richardson AC. Interpretation of linear and computed tomograms in the assessment of implant recipient sites. J Periodontol 1993 Dec; 64(12):12439.

13- Xie Q, Soikkonen K, Mattila K, Gong M, Ainamo A. Effect of head positioning in panoramic radiography on vertical measurements: an in vitro study. Dentomaxillofac Radiol1996 Apr; 25(2):61-6.

* Abbreviations of journal titles conform MEDLINE.

Recebido para publicação em: 15/10/2003

Encaminhado para reformulações em: 21/11/2003

Pronto para publicação em: 07/01/2004

\section{Correspondence to:}

Deborah Queiroz de Freitas

Rua Fritz Jacobs, 2752

Bairro N. S. Aparecida

CEP: 15025-500 São José do Rio Preto - SP

Tel.: (17) 235-1738

e-mail: deborahqf@uol.com.br 